\title{
Prior Knowledge in EFL Reading Comprehension: Native and Nonnative EFL Teachers' Perceptions, Classroom Strategies and Difficulties Encountered
}

\author{
Eid Alhaisoni \\ Department of English, College of Arts \\ University of Ha'il, Saudi Arabia
}

\begin{abstract}
This study investigates the perceptions of EFL native and nonnative teachers about the role of the prior knowledge in EFL reading comprehension, the instructional strategies used to activate students' prior knowledge, and the difficulties encountered when activating students' prior knowledge. Sixty-three EFL teachers in the preparatory year at Aljouf University participated in the study. The data were collected through a questionnaire and an observation checklist. The results showed a very strong agreement of the role of prior knowledge in text comprehension. Furthermore, teachers expressed strong agreement on the teacher's role in fostering text comprehension with the use of students' prior knowledge mainly by asking questions before, during and after reading, and providing students with suitable prior knowledge if they lacked it. The findings also showed that brainstorming strategies, audiovisual aids and questioning were very popular strategies used by the teachers. The results also revealed that teachers attributed the difficulties in activating their students' prior knowledge to the students' low level of reading, and limited linguistic competence. In light of the findings, some implications for EFL teachers, in-service teacher training, and for curriculum development are offered.
\end{abstract}

Keywords: Schema, prior knowledge, reading comprehension.

\section{INTRODUCTION}

Reading is an important skill and plays a dominant role among the four skills used in the learning of the English language. Reading ability is a basic and significant criterion on which to scale one's English level. It is acknowledged that in communication input and output, language comprehension is a very important key link that we cannot feel directly but does exist (An, 2011).

It was not until the 1950s and 60s that researchers began to conceptualise a theory about the whole reading process (Samuels and Kamil, 1988). At different periods, the construction of reading models was affected by the concepts of behaviorists and cognitivists. Reading is clearly considered a cognitive activity which, since the 1960s, has captured the interest of cognitive psychologists (Urquhart and Weir, 1998). These models not only affected our view of reading, but also of how reading was to be taught. For the past three decades, the bottom-top and top-down models have been very well known in the field of teaching. It should be pointed out that these models were primary developed for the L1, but researchers also applied them to EFL/ESL reading (Mushait, 2003).

Later in 1977 and 1988, Rumelhart, in response to the criticism of the bottom-top and top-down models, proposed an interactive model of reading that integrates both the bottom-top and the topdown processes of reading. This model aims to incorporate concurrently the process of obtaining knowledge from many different sources (linguistic and knowledge) while reading. It also allows for interaction between the two directions of processing - higher level and lower level processing. In 1984, Rumelhart expanded his interactive model of reading to the schema theory (ST) of reading which takes into account the role of higher level processing in reading comprehension without ignoring bottom-up processing. The main idea behind schemata is that readers can make sense of visual information and understand printed matter by relating them to their previous background knowledge (BK) and previous experience. In other words, ST tries to explain how people integrate the new information with the information they already have (Alderson, 2000). Schema theory has had a major influence on reading comprehension, which is viewed as an interactive process that requires the simultaneous performance of various mental operations. Berhnardt (1991) and Brantmeier (2004) 
pointed out that the activation of prior knowledge or schema is one of these operations. Studies on the role of prior knowledge (e.g. Murray, 1980 and Anderson, 1994) have shown that it has great impact on reading comprehension in a foreign language. These studies have made it clear that understanding the role of schema in the reading process provides deep insights into why students may fail or succeed in comprehending the written text.

Despite the large number of studies on the effects of prior knowledge on students' reading comprehension (Johnson, 1981; Carrell and Eisterhold, 1983; Barnet, 1989), there is lack of studies on how teachers understand the role of prior knowledge in EFL reading comprehension and what strategies they apply in the classroom to deal with it. August and Hakuta (1997), as cited in Chen (2003), pointed out that more research is needed to understand how to optimise reading comprehension instruction, especially in EFL contexts.

In Saudi Arabia, there is a lack of studies which explore how EFL teachers understand and implement ST in teaching reading. Many studies have investigated the reading strategies employed by students in a Saudi context (i.e. Alseweed, 2000; Mushait, 2003; Alkhalifa, 2010). Hence, this study aims to investigate teachers' perceptions of the role of prior knowledge, the strategies they use in the classrooms to activate students' prior knowledge, and the difficulties they encounter when activating prior knowledge in teaching reading.

\section{Research Questions}

1. What are EFL teachers' perceptions about the role of prior knowledge in reading comprehension?

2. What are the instructional strategies that teachers use to foster the activation of prior knowledge in the classrooms?

3. What are the difficulties that EFL teachers encounter when activating prior knowledge in the classrooms?

4. Are there any significant differences between native and nonnative EFL teachers in regard to the strategies used to foster the activation of prior knowledge?

\section{Literature REVIEW}

\subsection{Nature of Reading Comprehension}

Theorists vary on the nature of reading. Traditional opinions regard reading as a passive (bottom-top) decoding process. Thus it is believed that 'meaning is embodied in the text and the reader can extract the meaning from the print if he understands it letter by letter and word by word' (Goodman, 1988). At the same time, reading is considered 'primarily as a decoding process of reconstructing the author's intended meaning via recognising printed letters and words, and building up a meaning for a text from the smallest textual units at the "bottom" (letters and words) to larger and larger units at the "top" (phrase, clauses, intersectional linkages)' (Goodman, 1988). Reading is a decoding process. Hence, in teaching, the teacher focuses on the analysis of words. Surely, it can help students memorise new words or phrases in the reading, which then provides a strong foundation for the students reading and learning English. However, this model confines students to the learning of details (Zhao and Zhu, 2012).

Rumelhart (1985:57) argued that 'one's background knowledge plays a more important role than new words and new structures in reading comprehension'. Hence, in teaching reading, the teacher should teach the background knowledge first so that students equipped with such knowledge will be able to guess meaning from the printed page (Rumelhart, 1985). In this popular top-down model, readers do not need to focus on every word. They predict the meanings of the unknown words that they face. Obviously, in this model, students' prior knowledge is of great importance since it produces the ability to guess meaning during the reading process. However, this model requires corrections as it is often the case that a reader is easily led to wild guessing and misunderstanding (Mushait, 2003).

According to Eskey (1988), reading is an interactive process. This more balanced view of reading points to a constant interaction between bottom-up and top-down processes, with 'each source of information contributing a comprehensive reconstruction of [the] meaning of the text'. Heilman (1990) argued that the interactive view considers the significance of both the print and background knowledge in reading; it is the most applicable to reading instruction. 


\subsection{Schema Theory}

\subsubsection{Definition}

Bartlett (1932) defined schema as 'an active organisation of past reactions of past experiences, which must always be supposed to be operational in any well-adapted organic response'. Rumelhart (1980:34) defines schema as 'a data structure for representing the genetic concepts stored in memory'. He believes that schema theory is an explanation of how readers use prior knowledge to comprehend and learn from text. Anderson and Pearson (1984:42) define it as 'an abstract knowledge structure'. It is structured in the sense that it summarises what is known about a variety of cases that differ in many particulars and in that it represents the relationship among its components parts (Carrell, 1988). Medin and Russ (1992:246) define schema as 'a general knowledge structure used for understanding'. Schemata, on the whole, refer to the concepts that readers have about the world (Rumelhart, 1977).

\subsubsection{Types of Schemata}

There are three major types of schemata, namely, linguistics schemata, formal schemata and content schemata (Carrell, 1988).

\subsubsection{Linguistics Schemata}

A linguistic schema refers to the reader's existing linguistics knowledge about phonetics, grammar, vocabulary and idioms. Linguistic knowledge plays an essential part in text comprehension. Without linguistics schemata, it is impossible for the reader to decode and comprehend a text. Therefore, the more linguistic schemata a reader has in his/her mind, the faster the reader acquires information and the better understanding the reader may have. In other words, a second language reader should master certain linguistics knowledge to decode the text. Therefore, accumulated linguistic information is necessary for readers to obtain when they want to decode.

\subsubsection{Formal Schema}

A formal schema refers to 'background knowledge of the formal, rhetorical organisational structure of different types of texts' (Carrell and Eisterhold, 1988:71). It is 'abstract, encoded, internalised, coherent patterns of meta-linguistic, discoursed, and textual organisation that guide expectations in our attempts to understand a meaningful piece of language' (Carrell, 1983). It is knowledge of the ways in which different genres are presented. Readers use their schematic representations of the text, such as fictions, poems, essays, newspaper articles, academic articles in magazines and journals, to help comprehend the information in the text. Studies show that the knowledge of what type and genre the text is can facilitate reading comprehension for readers because the type of text will offer detailed evidence of the content of the text. Nonetheless, compared with linguistic and content schemata, formal schemata have less impacton the reading process (Carrell, 1984).

\subsubsection{Content Schema}

A content schema embodies the reader's pre-existing knowledge or real and imaginary worlds (Anderson et al., 1979) or refers to a reader's knowledge about the topic being read (James, 1987). Content schemata include topic familiarity, cultural knowledge and previous experience with a field. They deal with the knowledge relative to the content domain of the text, which is the key to understanding texts. To some extent, content schemata can make up for a lack of language schemata, and thus help learners understand texts by predicting, choosing information and removing ambiguities. Many studies have shown that readers' content schemata have a greaterinfluence on reading comprehension than formal schemata. On the whole, the familiarity with the topic has a direct influence on readers' comprehension. The more the reader knows about the topic, the more easily and quickly he gets the information from the text.

\subsubsection{Activation of Schema}

Cook (1989:69) states that 'the mind stimulated by key words or phrases in the text or by the context activates a knowledge'. Cook implies that we are not necessarily dealing with conscious processes, but rather with automatic cognitive responses, given external stimuli. This view clarifies that schemata are activated in one of two ways:

1. New information from the outside world can be cognitively received and related to already known information stored in the memory through retrieval or remembering. In this case, new concepts are assimilated into existing schemata which can be altered or expanded. 
2. New information can be represented by a new mental structure. In this case, in the absence of already existing schemata, new knowledge builds up new schemata.

According to Plastina (1997), in both cases the individual is piecing bits of knowledge together, in an attempt to make sense of them. It follows that the main features of schemata are flexibility and creativity. Schemata are flexible in that they undergo a cyclic process within which changes are brought about activity and economically, i.e. information is stored in the memory and provided when needed with the least amount of effort. They are creative in that they can be used to represent all types of experiences and knowledge - they are specific to what is being perceived.

Many studies have ascertained the significant effect of directly activating appropriate background information through pre-reading activities (see Hudson, 1982; Floyd and Carrell, 1987). Hudson (1982) used cue picture as stimuli and a questioning strategy to activate subjects' schemata, whereas Floyd and Carrell (1987) provided subjects with discussion, lectures and slide appreciation as prereading activities to activate, as well as construct, appropriate schemata. In addition to the traditional activities used by Hudson and Carrell, several methods, such as a pre-reading plan (Langer, 1981) andtext preview (Graves, Prenn and Cook, 1985) have been developed as effective strategies for facilitating reading comprehension. These well-developed activities, with explicit procedures to be followed, share the basic assumption that through proper questioning by teacher-initiated questions or student-generated questions, related background knowledge can be obtained (Anthony and Raphael, 1987).

Carrell $(1983,1987)$ indicates that ESL/EFL teachers should work on minimising their students' reading difficulties by providing them with familiar content that includes relevant cultural information. The selected reading materials must activate students' relevant schemata which will then lead to a better understanding of what is being read. Carrell (1983), Williams (1987), and other researchers showed that L2 reading comprehension may be affected not because L2 readers lack an appropriate schema, but because they fail to activate it.

Abraham (2002:6) states that 'teaching reading demands that teachers should activate the students' schema during the pre-reading phase by helping students recognise the knowledge that they already have about the topic of a text' on the premise that for a reader who is not actively using his/her background knowledge, a significant part of the reading process is not taking place. Moreover, Carrell and Floyd (1987) argue that teachers must provide their students with the appropriate schemata that they lack, and must also help them build a bridge between their existing and new knowledge. Moreover, teachers should have as their principal objective the development of problem-solving via creative, interpretive strategies in which students can exploit whatever knowledge or resources they may have. Hence, teachers should teach their students to activate and use their background knowledge to help them to become better readers.

\section{MethodS}

\subsection{Participants}

The sample participating in this study consisted of 63EFL native and nonnative teachers (34 males and 29 females) from 13 nationalities who volunteered to participate in the questionnaire and 23 teachers who agreed to be observed in their classrooms. The teachers teach English language to around 1400 Saudi EFL students enrolled in an intensive English language programme at the preparatory year study at Aljouf University. The aim of this programme is to prepare students for their undergraduate study.

\subsection{Instruments}

Two instruments were used for the purpose of the study - a questionnaire and an observation checklist. The questionnaire was adapted from Al-Jahwari and Al-Humaidi (2015) with some modifications. The questionnaire comprises 29 items and is divided into three parts. The first one deals with teachers' view about the role of students' prior knowledge in reading comprehension and the role of teachers in activating students' prior knowledge. The second part deals with the strategies used by teachers to activate students' prior knowledge. The last part deals with difficulties related to prior knowledge activation. A Cronbach's alpha calculated for this study also revealed acceptable reliability (.81). 
The internal reliability of the observation checklist was established by checking the performance of five teachers by two different observers, the researchers and a professor of applied linguistics at the Department of English at Aljouf University. Then, the reliability coefficient for the observation checklist was computed by calculating the percentage of agreement between the two observers which was $88 \%$.

\subsection{Data Collection}

The researcher observed 23 reading lessons of 23 teachers. The observed teachers were 11 native speakers from the USA, UK and Australia and 12 bilingual teachers from Jordan, Tunisia, India and Sudan. A week later, the researcher distributed the questionnaire to 63 teachers in the main hall of the English Language Centrein the preparatory year at Aljouf University. It took them 15 minutes to complete the questionnaire.

\section{RESUlts AND DiscuSSION}

Table1. Mean and Standard deviation of teachers' perceptions about the role of prior knowledge of a text's topic

\begin{tabular}{|l|l|l|l|}
\hline $\mathrm{N}$ & When students have sufficient prior knowledge about the topic, they can: & Mean & SD \\
\hline 1 & Understand the text better & 4.62 & .63 \\
\hline 2 & Recall information easily & 4.38 & .68 \\
\hline 3 & Read the text quickly & 3.81 & .92 \\
\hline 4 & Link the ideas in the text easily & 4.09 & .85 \\
\hline 5 & Focus on the main ideas & 3.95 & .93 \\
\hline 6 & Overcome limited linguistic knowledge & 3.57 & 1.09 \\
\hline 7 & Relate text to their own prior knowledge & 4.21 & 1.07 \\
\hline 8 & Predict text content easily & 4.07 & .79 \\
\hline 9 & Confirm predictions based on prior knowledge & 4.00 & .86 \\
\hline
\end{tabular}

Table 1 above shows the teachers' perceptions about the role of prior knowledge of a text's topic and answers our first research question: 'What are the instructional strategies teachers use to foster the activation of prior knowledge in the classrooms?' The findings reveal that EFL teachers strongly believe in the role of prior knowledge of the text's topic with mean average of 4.07, thus indicating high positive responses. The teachers believe that prior knowledge helps students to understand a text better; this statement came first with a mean of 4.62 and recall information easily came second with a mean of 4.38. However, the findings showed that the teachers' perception regarding the role of prior knowledge about a text's topic decreased for item number six, 'overcome limited linguistic knowledge' with a mean of 3.57, and item number three, 'read text quickly', with a mean of 3.81 . These findings indicate that the teachers in this study were fully aware of the role of sufficient prior knowledge about a text's topic in reading comprehension. Interestingly, although both scores are high, EFL teachers in this study assigned a much bigger role to prior knowledge in recall and comprehension than its role in helping students to solve their limited linguistic knowledge and to read texts quickly. This finding is supported by previous studies which showed that prior knowledge can enhance passage recall. Chiesi, Spillich, and Voss (1979) had adults rated as high or low in baseball knowledge recall a play-by-play account of a baseball game. They found that the recall of subjects rated as high in baseball knowledge were more coherent and that they preserved information important to the goals of the game in their recall, while the recall of subjects rated as low in baseball knowledge were more fragmented. In the Chiesi et al. study, high-knowledge subjects tended to recall information such as base hits, steals, and strikeouts more than low-knowledge subjects did, while lowknowledge subjects tended to recall more incidental information, such as the size of the crowd, than high-knowledge subjects did.

Anderson and Pichert (1978) found in their study that when subjects shifted perspective, homebuyers shifting to burglars and vice versa, they were able to recall information they did not previously recall. There is some evidence from the subjects' debriefing that they used their knowledge of the interests of homebuyers and burglars to examine their recall of the text, asking such questions as 'Did they discuss the silverware?' or 'Did they talk about the condition of the roof?' These effects may have been pronounced since the shift of perspective recall task took place 24 hours after reading the passage. Prior knowledge might not have as great an effect on more immediate recall when the exact wording may be fresher in readers' memories. 
Table2. Teachers' perceptions about the role of the teacher in fostering text comprehension

\begin{tabular}{|c|l|l|l|}
\hline $\mathrm{N}$ & $\begin{array}{l}\text { To foster text comprehension with the use of students' prior knowledge, it is } \\
\text { important for teachers to: }\end{array}$ & Mean & SD \\
\hline 1 & Provide students with appropriate prior knowledge & 4.48 & .64 \\
\hline 2 & Activate available prior knowledge & 4.61 & .75 \\
\hline 3 & Identify the absence of knowledge & 4.00 & .84 \\
\hline 4 & Raise students' awareness of the role of prior knowledge & 4.28 & .75 \\
\hline 5 & Ask questions before, during, and after reading & 4.65 & .57 \\
\hline 6 & Encourage students to summarise what they have read & 4.40 & .81 \\
\hline 7 & Elicit background information related to the reading topic & 4.45 & .68 \\
\hline
\end{tabular}

Table 2 shows the results of the teachers' views about the role of the teacher in fostering text comprehension. The findings reveal that the teachers believe strongly that a teacher has a great impact on and role in helping students foster text comprehension. Asking questions before, during, and after reading came first with a mean of 4.65. Moreover, 'activate available prior knowledge' and 'provide students with appropriate prior knowledge' had means of 4.61 and 4.84 respectively. These findings indicate that the teachers were fully aware of the importance of fostering text comprehension through the use of students' prior knowledge. Moreover, teachers may think that the techniques proposed in table 2 lead to automatic text comprehension without any attention to the types of these techniques. Zhao and Zhu (2012) argued that by asking questions at the pre-reading stage, teachers can create an active classroom atmosphere and arouse students' reading interest which makes them prone to using their previous knowledge. Whenever teachers or students decide on questions to be answered by reading, they are activating prior knowledge. Asking questions in the classrooms generated by the teacher or by the students should be done before the reading. Reutzel (1985) has proposed a reconciled reading lesson plan to help teachers form effective pre-reading questions. Teachers can adopt the reconciled reading questions from the comprehension questions that appear in the textbook after the reading selection or in the teachers' manual. A problem here is that not all the questions originally designed as post-reading exercises can be appropriately converted to pre-reading activities. Unpredictably, teachers gave less attention to identifying the absence of knowledge. Abraham (2002) and Carrell and Floyd (1987) reported in the literature that teachers should help students to first recognise their existing knowledge about the topic of a text and the knowledge they are lacking in order to help them build bridges between their existing and new knowledge.

Table3. Teachers' practices in reading classes

\begin{tabular}{|l|l|l|l|}
\hline $\mathrm{N}$ & $\begin{array}{l}\text { How frequently do you use the following strategies to activate students' prior } \\
\text { knowledge in text comprehension? }\end{array}$ & Mean & SD \\
\hline 1 & Brainstorming about the text's topic & 4.30 & .81 \\
\hline 2 & Class discussion about text's topic & 4.50 & .71 \\
\hline 3 & Organise the ideas on the board under headings to create relationships & 3.72 & .93 \\
\hline 4 & $\begin{array}{l}\text { Call students' attention to specific signal words, main ideas, sentences, highlighted } \\
\text { phrases, headings and subtitles }\end{array}$ & 4.32 & .72 \\
\hline 5 & $\begin{array}{l}\text { List some statements on the board that are related to the reading topic to guide } \\
\text { students' reading }\end{array}$ & 3.66 & .94 \\
\hline 6 & Use visually based questions & 3.98 & 1.08 \\
\hline 7 & Use supporting materials to display prior knowledge & 3.90 & .80 \\
\hline 8 & Develop inquiries about the text to create a purpose for reading & 4.02 & .85 \\
\hline 9 & Select key words from the text that require students to infer the text's topic & 4.10 & .98 \\
\hline 10 & Link the topic to students' culture and previous experiences & 4.17 & 095 \\
\hline
\end{tabular}

With regard to the strategies that are used by teachers to activate their students' prior knowledge in text comprehension, the findings in table 3 above show that class discussion about the text's topic came first with a mean of 4.50, followed by calling students' attention to specific signal words, main ideas, sentences, highlighted phrases, headings and subtitles with a mean of 4.3.Brainstorming strategies came third with a mean of 4.30. In contrast, listing some statements on the board that are related to the reading topic to guide students' reading and organising the ideas on the board under headings to create relationships were the strategies least used by the teachers in this study.

The results indicate that teachers were very familiar with the strategies and used them regularly in order to activate their students' prior knowledge. The findings are in line with what previous studies have found about pre-reading strategies (Carrell, 1983; Rowe and Rayford, 1987; Walraven and Reitsma, 1993; Spires and Donley, 1998). 
Prior Knowledge in EFL Reading Comprehension: Native and Nonnative EFL Teachers' Perceptions, Classroom Strategies and Difficulties Encountered

Nevertheless, we should bear in mind that teachers may claim that they use these strategies and they are aware of how important these strategies are, but in reality they do not. According to Cornford (2002) teachers claim that they use different reading strategies, but in reality, little explicit teaching and fostering of these specific strategies occur. Therefore, classroom observations are more effective for finding out which instructional strategies teachers actually use. In other words, classroom observation will help to close the gap between what teachers know or claim they know and what they are able to do in their classrooms. This will be discussed in the following section.

Table4. Observation checklist

\begin{tabular}{|l|l|l|}
\hline $\mathrm{N}$ & Strategies that have been observed with 23 teachers & Percentage \% \\
\hline 1 & Brainstorming & $100 \%$ \\
\hline 2 & Class discussion about the topic & $26 \%$ \\
\hline 3 & Semantic mapping & $13 \%$ \\
\hline 4 & Advance organiser & $0 \%$ \\
\hline 5 & Anticipation guide & $8 \%$ \\
\hline 6 & Use of audiovisual aids & $52 \%$ \\
\hline 7 & Questioning & $48 \%$ \\
\hline 8 & Prediction & $13 \%$ \\
\hline 9 & Link the topic to students' culture & $4 \%$ \\
\hline 10 & Know-Want to Know-Learned (KWL) chart & $0 \%$ \\
\hline
\end{tabular}

As mentioned in the methodology, 23 teachers were observed during their reading lessons to find out what strategies they use to activate their students' prior knowledge. The results show that all the observed teachers used brainstorming strategies in order to activate their students' prior knowledge. This result is consistent with the questionnaire results where we found that brainstorming was one of the reported strategies that teachers frequently use in their reading classrooms. The second most commonly used strategy was the use of audiovisual aids which 52\% of teachers used. Questioning strategies came third at $48 \%$. The other strategies were used infrequently.

According to Wallace (1992), one very popular type of pre-reading task is brainstorming. This may take the form of giving the class a particular key word or key concept, or it may be a newspaper headline or book title. Students are then invited to call out words and concepts they personally associate with the keyword or words provided by the teacher. Brainstorming has many advantages as a classroom procedure: first, it requires little teacher preparation; second, it allows learners considerable freedom to bring their own prior knowledge and opinions to bear on a particular issue; and third, it can involve the whole class. No learner need feel threatened when any bid is acceptable and can be added to the framework. For example, these are the kinds of associations which might be called up by the key word 'money': 'coin', 'bank', 'poverty', 'pay day', 'interest', 'purse', etc. These bids reflect very different categories and levels of generalisation. However, the initial random association can be classified and subcategorised either by the teacher or the students, and additional contributions from class members or the teacher function to stretch existing concepts (Ajideh, 2006).

It has been found that brainstorming can be an effective tool in teaching English as a foreign language. It has been documented in Labiod's (2007) study that prior knowledge activation through brainstorming enhances learners' reading comprehension. Richards (1990) recognised that brainstorming was effective in achieving student interaction in developing the cognitive skills for generating ideas. He found that students trained in brainstorming techniques were more successful at generating and organising ideas. Similarly, Rao (2007) found that students trained in brainstorming techniques and who utilised them regularly over a twelve-month period produced significantly higher results in writing tasks. In contrast, an attitudinal survey showed students' complacency about the effectiveness of brainstorming techniques. Brainstorming is regarded as an effective tool in creative problem-solving (Stein, 1975; Fernald and Nickolenko, 1993; Leclef, 1994). Its popularity can be traced back to the pervasive need to enhance the productivity of groups.

It is clear that teachers rely heavily on the use of 'brainstorming'. Brainstorming is just one strategy though, and teachers should use others to activate students' prior knowledge. Likewise, it was noted in the observation that many teachers did not use brainstorming in an efficient way. They did not spend much time in eliciting specific information about the topic by asking questions or using the title to introduce the reading text. This means that teachers view 'brainstorming' as an introduction to the 
reading text and as something they have to do in order to get students to read. Therefore, most teachers use the title only to remind students about similar topics they have already gone through and then guide them to the new reading text. The possible explanation for teachers' heavy reliance on a few strategies is that teachers may have limited training and knowledge about the instructional implications of prior knowledge in reading lessons. This makes teachers limit their instructional practices to only one or two simple pre-reading strategies, such as brainstorming and questioning. A lack of training became obvious in the inability of teachers to use more complex strategies such as 'advance organiser' and 'KWL' which were not used by any of the observed teachers. Another possible explanation for teachers' heavy reliance on brainstorming and questioning is that these strategies do not need much preparation and can be done easily before any lesson. It seems that EFL teachers' attention is usually focused on the content they need to teach and the information to be delivered, but not on understanding students' prior knowledge and helping them activate it. The researcher's notes from the observed lessons also indicate that teachers struggle to use the appropriate strategy to activate their students' prior knowledge.

Table5. Difficulties preventing students' prior knowledge activation

\begin{tabular}{|l|l|l|l|}
\hline $\mathrm{N}$ & What are the difficulties that prevent you from activating students' prior knowledge? & Mean & SD \\
\hline 1 & Lack of awareness of the role of prior knowledge & 3.58 & 1.18 \\
\hline 2 & Lack of knowledge about its instructional implications & 3.52 & .91 \\
\hline 3 & Lack of training on a variety of techniques & 3.63 & 1.10 \\
\hline 4 & Students' low level in reading & 3.72 & .78 \\
\hline
\end{tabular}

As shown in table 5 above, the mean scores of the four items were very close and ranged from 3.52 to 3.72. 'Students' low level in reading' was reported to be the greatest difficulty the teachers face when teaching reading with a mean of 3.72. Al-Qahtani (2016) interviewed 8 Saudi EFL teachers and asked them about their opinions on their Saudi students' reading skills. All the teachers indicated that Saudi EFL learners' reading abilities were generally poor. They claimed that they are 'unmotivated', 'struggling' and 'in constant need of help' during reading lessons. Furthermore, they claimed that almost ' $80 \%$ of students do not understand English texts'.

From my experience as an English language teacher for almost 19 years, the main two problems behind Saudi EFL learners' low level of reading which, in my point, view hinder the teachers from being able to activate their students' prior knowledge, are a low level of language proficiency and a limited vocabulary. As a result, the students will be unable to understand reading passages. Nezami (2012) conducted a study to investigate university-level EFL Saudi learners' comprehension strategies and reading skills and identified that some of problems for Saudi EFL readers are limited vocabulary, difficulty in understanding the meaning of the text, along with difficulties in prediction and in using prior knowledge.

Al-Jahwari and Al-Humaidi (2015) found in their study that Omani EFL teachers attributed their difficulty in activating prior knowledge to students' low level in reading. They believe that students' low ability in reading does not help them to use activation strategies.

Surprisingly, a majority of teachers indicated that they are suffering from a 'lack of knowledge about the role of prior knowledge' with a mean score of 3.58, as well as a 'lack of knowledge about its instructional implications', with a mean score of 3.52. This sounds contradictory if we bear in mind that respondents had already given strong agreements for the role of prior knowledge in reading comprehension as discussed earlier. Also, the results contradict teachers' responses in table 2 that they are familiar with the activation strategies and use them regularly to activate students' prior knowledge.

It is obvious that EFL teachers who participated in this study, regardless of their mother tongue and background education, were aware of the importance of the role of prior knowledge in reading comprehension, but that they had limited awareness of its instructional implications. It seems that they relied on the presence of students' prior knowledge and on their reading competence. Therefore, the low level of the students had a negative impact on the teachers' ability to activate students' prior knowledge. One possible explanation for this is that teachers lack training in a variety of techniques to activate students' prior knowledge. Another possible explanation is that a teacher's book does not provide teachers with enough information or strategies to help them in dealing with students' prior knowledge in order to enhance text comprehension. A teacher's book should also take into account the different abilities of teachers and that there are new teachers who have limited experience. 


\section{CONCLUSION}

This study aimed to explore EFL teachers' perceptions of the role of prior knowledge, the strategies used in the reading classrooms to activate students' prior knowledge and the difficulties encountered when activating prior knowledge in teaching reading. The participants were $82 \mathrm{EFL}$ teachers from different countries teaching English language in the preparatory year at Aljouf University. The results revealed that the teachers agreed that good prior knowledge about the text's topic has a great influence on students' recall and comprehension. Moreover, EFL teachers expressed strong agreement on the teacher's role in fostering text comprehension with the use of students' prior knowledge, mainly by asking questions before, during, and after reading, and by providing students with appropriate prior knowledge if they lack it. The findings of the questionnaire and observation showed that brainstorming strategies, audiovisual aids and questioning were very popular strategies used by the teachers. The results also revealed that teachers attributed the difficulties in activating their students' prior knowledge to the students' low level of reading and the fact that the students have limited linguistic competence which does not help them to express the wealth of knowledge they possess, or use it for constructing meaning. The results also showed that teachers lack adequate training on schema theory and its instructional implications and techniques and that teachers' books provide little help on how to deal with prior knowledge activation through a variety of techniques.

\subsection{Implications for Teaching $L 2$ Reading}

The results of the current study lead to several implications for EFL/ESL teachers. Teachers are supposed to help their students make connections between their prior knowledge and new reading materials through implementing different pre-reading activities. Teachers should also be aware that even though it might take them more time to prepare pre-reading activities and implement them, the benefits gained from these activities merit the effort as the activities contribute to improving learners' reading comprehension.

It is necessary for teachers to remember that the role of brainstorming is to facilitate the activation of students' background knowledge or schemata rather than to impose the opinions mentioned in the text. Moreover, the opinions expressed by students should not be judged or criticised at any cost; that is, learners should freely and spontaneously express their views, and as they hear their opinions, they can assess the rationality of their ideas which is in line with Weick, Sutcliffe, and Obstfeld's claim (2005) that learners can understand which concepts are important and evaluate the importance, correctness and relevance of what they had said through hearing their own ideas for the first time. In so doing, they can develop reflective thinking and higher-order level thoughts.

Teachers' limited awareness of prior knowledge and its implementation demands immediate action from supervisors and administrators. Teachers need to be taught how to implement several teaching practices. Therefore, more professional development through in-service teacher training is needed to aid teachers in the successful practice and implementation of a variety of background knowledge activation strategies. Teachers need to be provided with formal and informal training that guides them in the systematic utilisation of reading strategies aimed at enhancing reading comprehension. In this regard, the teacher's book can play an essential role in providing many examples of effective reading comprehension instructional techniques.

\section{REFERENCES}

Abraham, P. (2002). Skilled Reading: Top-down, bottom-up. Field Notes, 10 (2). SABES/World Education, Boston, MA.

Ajideh, P. (2006). Schema theory-based considerations on pre-reading activities in ESP textbooks. The Asian EFL Journal. 16, 1-19.

Alderson, J. C. (2000). Assessing Reading. Cambridge: Cambridge University Press.

Al-Jahwari \& Al-Humaidi, S. (2015).Prior Knowledge in EFL Reading Comprehension: Omani Teachers' Perspectives \& Classroom Strategies. International Journal of Applied Linguistics \& English Literature. 4 (1), 169-181.

Al-Issa, A. (2006). Schema theory and reading comprehension: implications for teaching. Journal of College Teaching \& Learning, 3(7), 41-48. 
Alderson, J. C. and Urquhart, A.H. (1984). Reading in a Foreign Language. London: Longman.

Alseweed, M. (2000). The effects of proficiency and training on the world-solving strategies of Arab EFL readers. Unpublished $\mathrm{PhD}$ Thesis. University of Essex. UK

Al-Qahtani, Why Do Saudi EFL Readers Exhibit Poor Reading Abilities? English Language and Literature Studies. 6 (1), 1-15.

Anthony, H. M. \& Raphael, T.E. (1987). Using question strategies to promote students' active comprehension of content material. ERIC Document Reproduction ServiceNo. ED 280011.

An, F. C. (2011). Schema Theory and Language Comprehension. Journal of Language and Literature Studies, 2, 4-7.

Anderson, R. C. (1994). Role of the reader's schema in comprehension, learning, and memory. Newark, Delaware: International Reading Association.

Anderson, R. C., \& Freebody, P. (1981). Vocabulary knowledge. In J. T. Guthrie (Ed.), Comprehension and teaching: Research reviews (pp. 77-117). Newark, DE: International Reading Association.

Anderson, R. C., \& Freebody, P. (1983). Reading comprehension and the assessment and acquisition of word knowledge. In B. Hutson (Ed.), Advances in reading/language research: A research annual (pp. 231-256). Greenwich, CT: JAI Press.

Anderson, R. C., \& Pearson, P. D. (1984). A schema-theoretic view of reading comprehension. In P.D. Pearson (Ed.), Handbook of reading research (pp. 255-291). New York: Longman.

Anderson, R. C., \& Pichert, J. W. (1978). Recall of previously unrecallable information following a shift in perspective. Journal of Verbal Learning and Verbal Behavior, 17, 1-17.

Bartlett, F. C. (1932). Remembering: A Study in Experimental and Social Psychology. Cambridge: Cambridge University Press.

Bernhardt, E.B. (1991). Reading development in a second language: Theoretical, empirical and classroom perspectives. Norwood, NJ: Ablex Publishing Corporation.

Brantmeier, C. (2004). Gender, violent-oriented passage content and second language reading comprehension. The Reading Matrix, 4(2), 1-19.

Carrell, P. L., \& J. C. Eisterhold. (1983). Schema Theory and ESL reading Pedagogy. TESOL Quarterly, 19, 81-92.

Carrell, P. L. (1984). Evidence of a formal schema in second language comprehension. Language Learning and Communication, 2, 87-112.

Carrell, P. (1987). Content and formal schemata in ESL reading. TESOL Quarterly, 21(3), 461-481.

Carrell, P. L. (1988). Some causes of text-boundedness and schema interference in ESL reading. In Carrell, P. L., J. Devine, \& D. E. Eskey (eds.), Interactive Approaches to Second Language Reading. Cambridge: Cambridge University Press.

Carrell, P., and P. Floyd (1989). Effects on ESL reading of teaching cultural content schemata. Language Learning, 37, pp. 88-108.

Chen, C. (2003). Mainstream teachers' practices and accommodations in pre-reading instructions for English language learners. Unpublished PhD thesis, University of Utah.

Chiesi, H. L., Spillich, G. J., \& Voss, J. F. (1979). Acquisition of domain-related knowledge in relation to high- and low-domain knowledge. Journal of Verbal Learning and Verbal Behavior, $18,257-272$.

Cook, G. (1989) Discourse in language teaching: A scheme for teacher education. Oxford: Oxford University Press.

Cornford, I. R. (2002). Learning-to-learn strategies as a basic foe effective lifelong learning. International Journal of lifelong Education, 21(4), 357-368.

Eskey, D. E., \& W. Grabe. (1988). Interactive models for second language reading: perspectives on instruction. In Carrell, P. L. et al. (eds.), Interactive Approaches to Second Language Reading. Cambridge: Cambridge University Press.

Eskey, D. E. (1988). Holding in the Bottom: An Interactive Approach to the Language Problems of Second Language Readers. Cambridge: Cambridge University Press. pp. 93-111. 
Prior Knowledge in EFL Reading Comprehension: Native and Nonnative EFL Teachers' Perceptions, Classroom Strategies and Difficulties Encountered

Fernald, L. W. \& Nickolenko, P. (1993). The creative process: Its use and extent of formalization by corpo-rations. Journal of Creative Behavior, 27(3), 214-220.

Floyd, P., \& Carrell, P.L. (1987). Effects on ESL reading of teaching cultural content schemata. Language Learning, 37 (1), 256-280.

Freebody, P., \& Anderson, R. C. (1983). Effects of vocabulary difficulty, text cohesion, and schema availability on reading comprehension. Reading Research Quarterly, 18, 277-294.

Goodman, K. (1970). Reading as a psychologistic guessing game. In H. Singer and R. b. Ruddell. (Eds). Theoretical models and Processes of Reading. Newark, N.J.: International reading Association.

Goodman, K. (1988). Interactive Approaches to Second Language Reading. Cambridge: Cambridge University Press. pp. 42-45.

Grabbe, W. (1991). Current developments in second language reading research. TESOL Quarterly 25(3), 375-406.

Graves, M.F., Prenn, M.C., \& Cooke, C.F. (1985). The coming attraction: previewing short stories. Journal of Reading, 28, 594-598

Heilman, A. W., Blair, T. R., \& Ruply, W. H. (1990). Principles and practices of teaching reading. London: Merrill Publishing Company. p. 117.

Hudson, T. (1982). The effects of Induced Schemata on the 'Short-Circuit' in L2 reading: Nondecoding Factors in L2 Reading performance. Language Learning 32 (1982): 1-32.

James, M. O. (1987). ESL reading pedagogy: Implications of schema-theoretical research.

In J. Devine, P.L. Carrell, \& D.E. Eskey (Eds.), Research in reading in English as a second language, (pp.175-188). Washington, D. C.: Teachers of English to Speakers of Other Languages.

Johnson, P. (1981). Effects on reading comprehension of language complexity and cultural background of a text. TESOL Quarterly, 16, 169-181.

Johnson, P. (1982). Effects on reading comprehension of building background knowledge. TESOL Quarterly, 16, 503-516.

Johnson, P. (1983). Assessing reading comprehension. Newark, DE: International Reading Association.

Labiod, A. (2007). Prior Knowledge Activation through Brainstorming to Enhance EFL Learners' Reading Comprehension. The Case of Second Year Learners at the ENS, Constantine. Unpublished MA dissertation (Reading and Writing Convergences).

Langer, A. \& Nicolich, M. (1980). Effect of Altered Prior Knowledge on Passage Recall. Eric. ED 1 97282

Leclef, F. (1994). 132 managers talk about creativity consultancy. In H. Geschka, S. Moger, \& T. Rickards (Eds.), Creativity and Innovation: The power of synergy (pp. 45-49). Darmstadt, Germany: Geschka \& Partner Unternhmensberatung.

Mushait, S. (2003). The relationship of $L 1$ reading and $L 2$ language proficiency with the $L 2$ reading comprehension and strategies of Saudi EFL university students. Unpublished $\mathrm{PhD}$ thesis. University of Essex, UK

Murray. (1980). The effect of two techniques which elicit productive response on the comprehension of content area reading materials. Unpublished MA dissertation. The University of Connecticut.

Nezami, S. (2012). A critical study of comprehension strategies and general problems in reading skill faced byArab EFL learners with special reference to Najran University in Saudi Arabia. International Journal of Social Sciences and Education, 2(3), 306-316.

Plastina, A.F. (1997). MA in Linguistics (TESOL) University of Surrey, U.K. Unpublished.

Rao, Z. (2007). Training in brainstorming and developing writing skills. ELT Journal, 61(2), 100-106

Rowe, D.W, \& Rayford, L. (1987). Activating background knowledge in reading comprehension assessment. Reading Research Quarterly, 22(2), 160-176.

Reutzel, D. R. (1985). Reconciling schema theory and the basal reading lesson. The Reading Teacher, 39, 2, pp. 194-198. 
Richards J. (1990). New Trends in the Teaching of Writing in ESL/ EFL, in Wang Z. (ed.) ELT in China. Papers Presented at the International Symposium on Teaching English in the Chinese Context, Foreign Language Teaching and Research Press, Beijing

Ringler, L. h. \& Weber, C.K. (1984). A language -Thinking Approach to Reading. San Diego: Harcourt Brace Jovanovich, Ink.

Rumelhart, D. E. (1977). Toward an Interactive Mode of Reading. In Dornic (ed), Attention and Performance IV, 6, 573-601.

Rumelhart, D. E. (1980). Schemata: the building blocks of cognition. In R. J. Spiro, B. C. Bruce, \& W. F. Brewer (eds), Theoretical Issues in Reading Comprehension. Hillsdale, New Jersey: Lawrence Erlbaum Associations. pp. 77-85.

Rumelhart, D. E. (1985). Toward an Interactive Model of Reading. Newark, DE: International Reading Association. p. 47.

Rowe, D.W, \& Rayford, L. (1987). Activating background knowledge in reading comprehension assessment. Reading Research Quarterly, 22(2), 160-176.

Samuels, S. \& Kamil, M. (1988). Models of the reading process. In P. Carrell, J. Davine, \& D. Eskey, (Eds.), Interactive approaches to second language reading (pp. 22-36).

Spires, H.A. \& Donley, J. (1998). Prior knowledge activation: Inducing engagement with informational texts. Journal of Educational Psychology, 90, 1-12.

Stein, M. I. (1975). Stimulating creativity: Group procedures (Volume two). NY: Academic Press

UR, P. (1996). A Course in Language Teaching. Cambridge: Cambridge University Press.

Urquhart, S. \& Weir, C. (1998). Reading in a second language: Process, product and practices. London, Longman.

Wallace, C. (1992). Reading. Oxford: Oxford University Press.

Walraven, M. \& Reitsma, P. (1993). The effect of teaching strategies for reading comprehension to poor readers and the possible surplus effect of activating prior knowledge. National Reading Conference Yearbook, 42, 243-250.

Weick, Karl E., Kathleen M. Sutcliffe, \& David Obstfeld (2005). 'Organizing and the process of sense making'. Organization Science 16,409-421.

Williams, E. (1987). Classroom reading through activation of content-based schemata. Reading in a Foreign Language, 4, 1, 1-7.

Zhao, X \& Zhu, L. (2012). Schema Theory and College English Reading Teaching. English Language Teaching, 5 (11). 111-117. 